\title{
ON THE INFLUENCE OF PLANT COVER UPON SOIL TEMPERATURE
}

\author{
YRJö Pessi \\ Frost Research Station, Pelsonsuo
}

Received February 28, 1953

A number of investigations relating to the temperature in the soil have been performed at the Frost Research Station, Pelsonsuo (2, 3, 4, 5). Almost without exception the soil surface has been kept bare in these investigations. This was done for the following reasons: The investigations have concerned, for instance, the annual variation of the thermal conditions in the soil and the significance of soil type in regard to the character of these thermal conditions. As the plant cover has an effect upon soil temperature (v., e.g., 1, 6, 7), the presence of plant cover might have disturbed the investigations inasmuch as it would not have been similar in all the years of investigation and on all investigated sites. For instance, it might not have been equally dense or equally erect, etc. Similarity of conditions could most readily be obtained by keeping the soil bare of vegetation.

However, an investigation carried out in this manner only gives a correct idea of the thermal conditions in the soil at the site of growth of cultivated plants up to the time when the superterrestrial parts of the plants would begin to shade the soil surface. For this reason temperature measurements have been made at the Frost Research Station also in soil growing cereal plants so as to find out in which way the plant cover affects the soil temperatures in the cultivated peat land of the Station. These investigations will be described in the following.

\section{Methods of investigation}

The soil temperatures were measured with the aid of thermocouples $(3$, p. 17). Two thermocouples each were used at depths of 10 and $20 \mathrm{~cm}$ at each point of measurement, whereas only one thermocouple was inserted $100 \mathrm{~cm}$ below the soil surface. The procedure of inserting the thermocouples has been described before (3, p. 31). The daily mean temperatures were computed on the basis of observations taken at 8.00 and 20.00 hours, in the same way as in an earlier investigation (2, p. 12). The plant cover on the sites consisted of fully dense oats in 1955 and of fully 


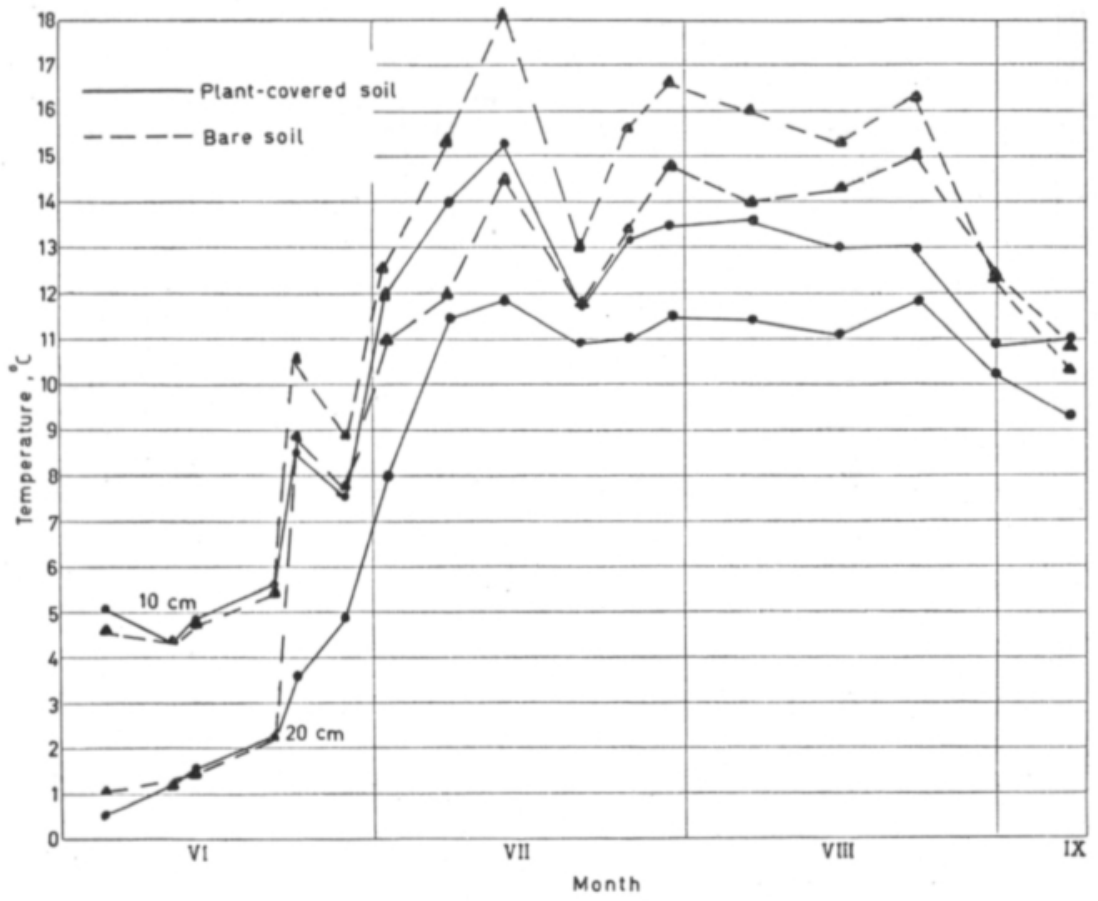

Fig. 1. Soil temperatures at 10 and $20 \mathrm{~cm}$ depth, 1955.

dense barley in 1956. The barley lodged about the middle of August, while the oats remained upright throughout the time of investigation. Each year the sprouts of the cereal began to shade the soil surface about June 20th.

\section{Results of investigation}

The mean temperatures of the observation days are shown in Fig. 1 and 2 . It appears that after the plants have begun to shade the soil surface, the daily mean temperature at a depth of 10 and $20 \mathrm{~cm}$ has been lower than on the sites with bare soil surface. The temperature differences amount mostly to $3-4^{\circ} \mathrm{C}$. The influence of the plant cover is also evident in the temperature at $100 \mathrm{~cm}$ depth (Fig. 2).

The course of temperature is different on the different sites in that the temperature at $10 \mathrm{~cm}$ depth has been higher than at $20 \mathrm{~cm}$ throughout the time of investigation on the plant-covered sites, whereas under bare soil the temperature at $10 \mathrm{~cm}$ depth falls below that at $20 \mathrm{~cm}$ in the first half of September.

TAMm (6, p. 94) has found that in a rye field the soil temperature at $5 \mathrm{~cm}$ depth was higher by $2-3^{\circ} \mathrm{C}$ in May and June than in a lucerne field. Under bare soil the temperature was $1-2^{\circ} \mathrm{C}$ higher than in the rye field. In a potato field, again, the soil temperature has not fallen below that under bare soil before AugustSeptember. 


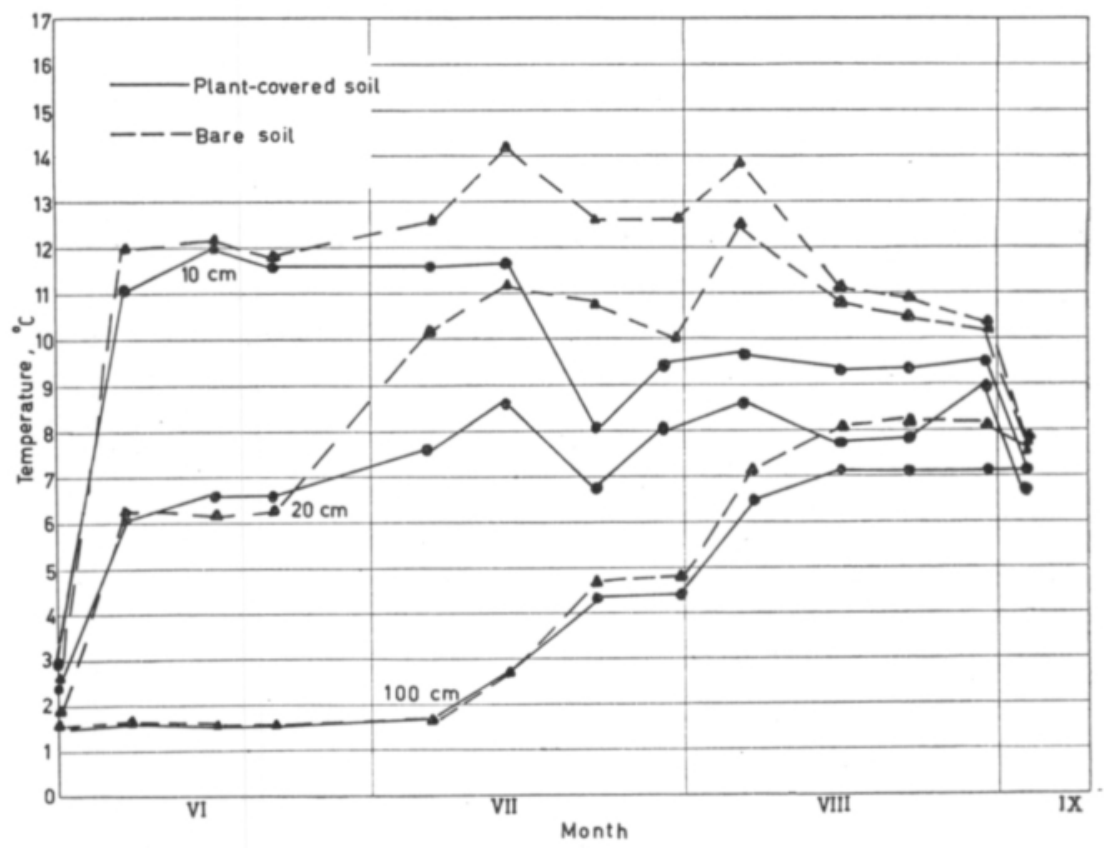

Fig. 2. Soil temperatures at 10, 20, and $100 \mathrm{~cm}$ depth, 1956.

The plant cover also damps the daily variation of temperature in the soil. The daily temperature amplitude on August 15, 1955 was found to have the following values:

\begin{tabular}{lcc} 
& \multicolumn{2}{c}{ Daily amplitude, ${ }^{\circ} \mathrm{C}$} \\
& \multicolumn{2}{c}{ Depth } \\
& $10 \mathrm{~cm}$ & $20 \mathrm{~cm}$ \\
Plant-covered soil & 2.6 & 0.6 \\
Bare soil & 4.9 & 2.7
\end{tabular}

S E L O T U S :

KASVILLISUUDEN VAIKUTUKSESTA MAAN LÄMPÖTILAAN

YRJö PESSI

Hallakoeasema, Pelsonsuo

Hallakoeasemalla on suoritettu joukko maan lämpöoloja koskevia tutkimuksia, joiden yhteydessä maan pinta on pidetty vapaana kasvillisuudesta. Tämä menettely on johtunut seuraavista seikoista. On tutkittu kysymyksiä, kuten maan lämpöolojen vuotuisia vaihteluja ja eri maalajien lämpöoloja. Kun kasvipeitteellä on merkitystä maan lämpötilaan, olisi kasvipeite saattanut häiritä tutkimuksia siinä mielessä, ettei se kaikkina vuosina ja kaikilla tutkimuspaikoilla olisi ollut samanlainen. Samanlaiset olosuhteet pystyttiin luomaan parhaiten siten, että maan pinta pidettiin paljaana. 
Tällä tavoin suoritetut tutkimukset eivät anna kuitenkaan oikeata kuvaa maan lämpöoloista kasvien kasvupaikalla muuta kuin siihen saakka, jolloin kasvin maanpääliset osat alkavat varjostaa maan pintaa. Tämän vuoksi on koeasemalla suoritettu maan lämpötilanmittauksia myös kasvillisuuden kohdalla.

Lämpötilamittaukset suoritettiin termoelementeillä 10, 20 ja eräănä vuonna myös $100 \mathrm{~cm}: \mathrm{n}$ syvyyksissä. Tuloksista ilmeni, että sen jälkeen kun vilja alkoi varjostaa maata, vuorokauden keskilämpötila muodostui 10 ja $20 \mathrm{~cm}: n$ syvyyksissä alhaisemmaksi kuin maan pinnan ollessa paljas. Tavallisimmat lämpötilaerot olivat $3-4^{\circ} \mathrm{C}$. Kasvillisuiuden vaikutus tuntui myös $100 \mathrm{~cm}$ :n syvyyden lämpötilassa.

\section{KIRJALLISUUTTA}

(1) BiebL, R. 1951. Bodentemperaturen unter verschiedenen Pflanzengesellschaften. Aus den Sitzungsberichten der Österr. Akademie der Wissenschaften. Mathem.-naturv. Kl. Abt. I. 160. 1: $71-90$.

(2) Pessi, Y. 1956. On the effect of rolling upon the barley and oat crop yield and upon the thermal conditions of cultivated peat land. (Selostus: Jyräyksen vaikutuksesta ohran ja kauran satoon sekä suoviljelyksen lämpöoloihin.) Valt. maat.koet. julk. 151: 1-23.

(3) $\rightarrow$ 1956. Studies on the effect of the admixture of mineral soil upon the thermal conditions of cultivated peat land. (Selostus: Tutkimuksia kivennäismaan sekoituksen vaikutuksesta suoviljelyksen lämpöoloihin). Ibid. 147: 1-89.

(4) $\rightarrow$ 1957. On the thermal conditions in mineral and peat soil at Pelsonsuo in $1955-1956$. (Selostus: Kivennäismaan ja turvemaan lämpöoloista Pelsonsuolla vuosina 1955-1956). Ibid. (in print).

(5) $\longrightarrow$ 1957. Suoviljelyksen maan lämpöoloista Pelsonsuolla vuosina 1952-1955. . (Summary: On the thermal conditions of cultivated peat soil at Pelsonsuo in the years 1952-1955). Ibid. (in print).

(6) Tамм, E. 1950. Bodentemperaturen unter verschiedenen Pflanzenbeständen. Z. Pfl. Ern. Düng. Bodenk. 47: $29-34$.

(7) Angstrôm, M. A. 1937. Jordtemperaturen i bestånd av olika täthet. Medd. stat. skogsforskn. anst. 29, 3: $1-32$. 